\title{
Urgensi Judicial Review Satu Atap Oleh Mahkamah Konstitusi
}

\author{
Tenri Wulan Aris \\ Pascasarjana Universitas Islam Indonesia, e-mail: twulanaris@gmail.com
}

\begin{abstract}
The Constitutional Court and the Supreme Court are judicial power actors who, based on the provisions of the constitution, have the same authority to examine judicial regulations even at different levels. The Constitutional Court examines the law against the Basic Law, while the Supreme Court examines the statutory provisions under the law against the law. These provisions cause a power point of contact between the Constitutional Court and the Supreme Court in a judicial review. the tangent precisely in practice has the potential to cause polemic, as happened in the decision of the Constitutional Court No. 30 / PUU-XVI / 2018 and MA Decision No.65 P / HUM / 2018. These two decisions actually contradict each other in deciding the legal status of political party functionaries who are running for candidates for DPD members. The potential to cause a lot of polemic with the practice of judicial review on two roofs proves the need for proper legal politics to address this issue. In this study using the method of doctrinal research, using a theoretical approach (theoretical approach), a statutory approach, and a conceptual approach. Sources of data used in the form of primary and secondary legal materials through literature review. This study concludes that the concept of two-roof testing practiced in Indonesia is not an ideal choice because it raises many problems, both technically and theoretically. Thus, placing the Constitutional Court as the sole institution authorized to conduct legal norm testing is a legal political choice that is needed today in order to realize effective justice that provides legal certainty for justice seekers.
\end{abstract}

Keywords: One Roof Judicial Review; Constitutional Court; Supreme Court

\section{PENDAHULUAN}

Hadirnya Mahkamah Konstitusi dalam sistem ketatanegaraan Indonesia membawah konsekuensi terhadap cabang kekuasaan kehakiman di Indonesia yakni praktik kekuasaan kehakiman dengan sistem bifurkasi (bifurcation system). Dalam sistem bifurkasi, kekuasaan kehakiman dibagi menjadi dua cabang utama, yaitu cabang peradilan biasa (ordinary court) yang bermuara pada Mahkamah Agung dan cabang peradilan konstitusi (constitutional court) yang mempunyai wewenang untuk melakukan judicial review suatu produk undang-undang terhadap konstitusi, dalam hal ini dilakukan oleh Mahkamah Konstitusi. ${ }^{1}$ Namun, pelaksanaan wewenang judicial review dalam praktik ketatanegaraan di Indonesia tidak secara absolut memberikan

1 Abdul Hakim Garuda Nusantara, "Mahkamah Konstitusi: Perspektif Politik dan Hukum”, Kompas, 24 September 2002. Dikutip dari Ni’matul Huda, (2008), UUD 1945 dan Gagasan Amandemen Ulang, Jakarta: Rajawali Pers, hlm 252. 
kewenangan kepada Mahkamah Konstitusi melainkan juga kepada Mahkamah Agung dalam pelaksanaan kewenangan judicial review.

Kewenangan judicial review merupakan mekanisme kontrol terhadap pembuatan peraturan perundang-undangan yang dikeluarkan dengan kualitas rendah, atau bahkan peraturan perundang-undangan tersebut memuat materi yang merugikan warga negara. Namum mekanisme pengujian peraturan perundang-undangan yang dipraktikkan di Indonesia dengan sistem dua atap justru berpotensi menimbulkan konflik hukum baru.

Apabila di telisik lebih jauh kebelakang, banyak sekali konflik hukum yang yang terjadi antara Mahkamah Konstitusi dan Mahkamah Agung. Konflik hukum yang dimaksud adalah banyaknya putusan antara Mahkamah Konstitusi dan Mahkamah Agung yang saling bertentangan dalam menilai suatu isu hukum sehingga menimbulkan ketidakpastian hukum bagi para pencari keadilan (justiciabelen) dan masyarakat secara umum.

Pertentangan norma tersebut terjadi, misalnya pada putusan terkait dengan sifat melawan hukum materiil dalam perkara Tindak Pidana Korupsi (Tipikor). ${ }^{2}$ Kemudian putusan kasasi Mahkamah Agung Nomor 1.110/K/Pid.Sus/2012 yang dalam putusannya justru menggunakan dasar hukum yang telah dinyatakan tidak sah dan mengikat oleh Mahkamah Konstitusi. ${ }^{3}$ Kasus lain yang cukup menimbulkan kontroversi adalah persoalan mengenai legalitas calon anggota Dewan Perwakilan Daerah (DPD) yang berasal dari unsur partai politik. Mengenai persoalan ini Mahkamah Konstitusi dan Mahkamah Agung kemudian mengeluarkan putusan yang kontras dalam menilai isu hukum tersebut. Mahkamah Konstitusi dalam putusannya Nomor 30/PUU-XVI/2018 memutuskan jika pengurus partai politik tidak bisa mencalonkan diri sebagai calon anggota DPD, sementara Mahkamah Agung melalui putusan Nomor 65 P/HUM/2018 justru memutuskan jika pengurus partai politik bisa mencalonkan diri sebagai calon anggota DPD pada pemilu 2019. Hadirnya perbedaan dalam menilai isu hukum tersebut diakibatkan dari desain kewenangan judicial review dalam satu atap. Terjadinya perbedaan putusan dalam perkara yang serupa tentu tidak baik dan bertentangan dengan kepastian hukum. ${ }^{4}$

Persoalan rumit lain yang akan terjadi apabila model pengujian peraturan perundangundangan tetap berada dalam dua atap adalah dalam hal penentuan subjek pengujian pada saat dilakukan judicial review peraturan perundang-undangan di bawah UndangUndang terhadap Undang-Undang, namun produk hukum yang diuji tersebut tidak bertentangan secara langsung dengan Undang-Undang sebagai batu uji tetapi

\footnotetext{
${ }^{2}$ Terjadi dualisme penegakan hukum Pasca Putusan Mahkamah Konstitusi Nomor 033/PUUIV/2006. Mahkamah Konstitusi dalam putusan tersebut memutuskan bahwa penerapan "sifat melawan hukum materiil" dalam penjelasan Pasal 2 ayat (1) Undang-Undang Nomor 31 tahun 1999 jo. Undang Undang Nomor 20 tahun 2001 tentang Pemberantasan Tindak Pidana Korupsi dinyatakan inkonstitusional. Namun, Mahkamah Agung pasca putusan tersebut ternyata masih menggunakan penafsiran "sifat melawan hukum materiil" mengikuti yurisprudensi, misalkan dalam putusan Nomor $103 \mathrm{~K} / \mathrm{Pid} / 2007$.

${ }^{3}$ Mahkamah Agung dalam putusan pada tingkat kasasi Nomor 1.110/K/Pid.Sus/2012 menjatuhkan hukuman dengan menggunakan dasar hukum yang telah dibatalkan oleh Mahkamah Konstitusi yakni Pasal 76 UU No. 29 tahun 2004 tentang Praktek Kedokteran, pembatalan terhadap pasal tersebut dimuat dalam Putusan Mahkamah Konstitusi No. 4/PUU-V/2007 tentang Pengujian terhadap UU No. 29 tahun 2004 tentang Praktek Kedokteran.

${ }^{4}$ Lihat Putusan MK No. 30/PUU-XVI/2018 dan Putusan Mahkamah Agung No. 65 $\mathrm{P} / \mathrm{HUM} / 2018$
} 
bertentangan langsung dengan aturan yang lebih tinggi, dalam hal ini Undang-Undang Dasar.

Hadirnya kewenangan judicial review merupakan perkembangan dari gagasan modern tentang negara hukum demokratis. Secara teoritik dimaksudkan: pertama, mencegah warga negara dari dominasi kekuasaan atau penyalahgunaan kekuasaan (abuse of power) oleh lembaga negara, serta menjamin berfungsinya sistem demokrasi dalam hubungan peran antara cabang kekuasaan eksekutif, legislatif, dan yudikatif. Kedua, menjamin dan melindungi agar setiap warga negara terlindung dari penyalahgunaan kekuasaan yang dapat mencedrai hak-hak fundamental yang dijamin oleh konstitusi. ${ }^{5}$

Konflik hukum yang terjadi antara Mahkamah Konstitusi dan Mahkamah Agung mungkin akan terus menimbulkan persoalan apabila masih terjadi dualisme pengujian norma hukum di Indonesia. Karena tidak mustahil terjadi persinggungan normatif secara vertikal yang justru bersifat kontradiktif, hal tersebut sangat mungkin apabila dalam praktik kedua lembaga tersebut menggunakan paradigma hukum yang berbeda untuk pengujian peraturan perundang-undangan terkait, yang dapat saja berujung pada putusan yang berbeda secara mencolok.

\section{METODE PENELITIAN}

Penelitian ini merupakan jenis penelitian doktrinal ${ }^{6}$, karena selama yang dikaji adalah norma hukum maka penelitian tersebut merupakan penelitian hukum doktrinal. Adapun dalam penelitian ini menggunakan sumber bahan hukum yang meliputi bahan hukum Primer (primary sources of authorities), bahan hukum sekunder (secondary sources of authorities), serta bahan hukum tersier. Dalam penelitian hukum yang dimaksudkan dengan bahan hukum primer adalah semua norma hukum yang berkaitan dengan penelitian ini, dibentuk atau dibuat secara resmi oleh lembaga negara yang berwenang membuat aturan tersebut. ${ }^{7}$ Untuk bahan hukum sekunder adalah seluru informasi tentang hukum, seperti karya-karya akademis, buku, hasil penelitian, dan lainnya. Sementara untuk bahan hukum tersier merupakan bahan-bahan yang melengkapi bahan hukum primer dan bahan hukum sekunder. ${ }^{8}$

Penelitian ini menggunakan teknik pengumpulan data bahan hukum dengan studi kepustakaan, yaitu mengkaji berbagai aturan-aturan terkait yang relevan dengan penelitian dan literatur-literatur lainnya yang berhubungan dengan penelitian ini. Dalam penelitian ini menggunakan tiga metode pendekatan, yakni: pertama, pendekatan kasus (case approach), adalah pendekatan dengan menelaah kasus-kasus berkaitan dengan penelitian ini. Kedua, pendekatan perundang-undangan (statute approach), adalah pendekatan dengan menelaah peraturan perundang-undangan yang terkait dengan penelitian. Ketiga, pendekatan konseptual (conceptual approach), pendekatan ini dipilih karena penelitian ini beranjak doktrin-doktrin dalam bidang ilmu hukum. Dari penelitian

\footnotetext{
${ }^{5}$ Jimlly Ashiddiqie, (2005), Model-Model Pengujian Konstitusional Di Berbagai Negara, Jakarata: Konstitusi Press, hlm 11.

${ }^{6}$ Penelittian hukum dibagi dalam dua ragam pendekatan yaitu, (i) pendekatan penelitian hukum doktrinal; (ii) pendekatan penelitian hukum non-doktrinal. Lihat Soetandyo Wignjosoebroto, (2013), Hukum Konsep Dan Metode, Malang: Setara Press, hlm 35.

${ }^{7}$ Ibid., hlm 79.

8 Soerjono Soekanto dan Sri Mamudji, (2007), Penelitian Hukum Normatif: Suatu Tinjauan Singkat, Jakarta: PT. RajaGrafindo Persada, hlm 33.
} 
ini diharapkan dapat menemukan konsep ideal pengujian peraturan perundang-undangan dalam sistem ketatanegaraan Indonesia. Penelitian ini juga menggunakan teknik analisis deskriptif kualitatif.

\section{ANALISIS}

\section{Permasalahan Judicial Review Dua Atap}

Konsep judicial review secara sederhana dipahami sebagai konsep untuk menguji peraturan tertulis yang dilakukan oleh lembaga peradilan. Istilah judicial menunjukan kewenangan lembaga judiciary.Sementara, cakupan pengertiannya sangat luas karena tidak hanya menyangkut segi-segi konstitusionalitas objek yang diuji, tetapi juga berkaitan dengan segi-segi legalitasnya berdasarkan peraturan perundang-undangan dibawah UUD. ${ }^{9}$

Judicial review merupakan kewenangan lembaga peradilan untuk menguji keabsahan dan daya laku produk-produk hukum yang dihasilkan oleh eksekutif, legislatif, maupun yudikatif dihadapan konstitusi yang berlaku. Pengujian oleh hakim terhadap produkproduk cabang kekuasaan legilatif dan eksekutif adalah konsekuensi dari dianutnya prinsip check and balances berdasarkan pada doktrin pemisahan kekuasaan (separation of power). ${ }^{10}$ Oleh karena itu, kewenangan untuk melakukan judicial review melekat pada fungsi hakim sebagai subjeknya, bukan pada pejabat lain. Jika pengujian dilakukan bukan oleh hakim, tetapi oleh lembaga parlemen maka pengujian tersebut dinamakan legislative review. Jika pengujian perundang-undangan dilakukan oleh pemerintah yang berada pada struktur yang lebih tinggi terhadap produk perundang-undangan yang dihasilkan oleh pemerintah yang berada dibawahnya, maka pengujian tersebut dinamakan administrative review atau executive review. ${ }^{11}$ Konteks tulisan ini, yang dimaksud dengan pengujian ialah yang diberikan kepada lembaga peradilan, sehingga disebut sebagai judicial review.

Judicial review dalam sistem hukum Indonesia memberikan dan membagi kewenangan tersebut kepada dua lembaga kekuasaan kehakiman, yaitu Mahkamah Konstitusi dan Mahkamah Agung. Mengenai pembagian kewenangan judicial review antara Mahkamah Agung dan Mahkamah Konstitusi sudah secara eksplisit diatur dalam UUD NRI Tahun 1945 tepatnya dalam ketentuan Pasal 24A ayat (1) mengatur bahwa: "Mahkamah Agung berwenang mengadili pada tingkat kasasi, menguji peraturan perundang-undangan di bawah undang-undang terhadap undang-undang, dan mempunyai kewenanagan lain yang diberikan oleh undang-undang". Sementara itu dalam ketentuan pasal 24C ayat (1) mengatur bahwa: "Mahkamah konstitusi berwenang mengadili pada tingkat pertama dan terakhir yang putusannya bersifat final untuk menguji undang-undang terhadap Undang Undang Dasar, memutus sengketa wewenang lembaga negara yang kewenangannya diberikan oleh Undang Undang Dasar, memutus pembubaran partai politik, dan memutus perselisihan tentang hasil pemilihan umum".

Merujuk pada ketentuan di atas maka kewenanagn judicial review yang dimiliki oleh Mahkamah Konstitusi dan Mahkamah Agung terdapat perbedaan dalam hal obyek dan

\footnotetext{
${ }^{9}$ Jimly Ashiddiqie, Model-Model ... op. cit., hlm 2-3.

${ }^{10}$ Abdul Mukthie Fadjar,(2006), Hukum Konstitusi Dan Mahkamah Konstitusi, Cetakan Pertama, Jakarta: Konstitusi Press dan Citra Media, hlm 34-35..

${ }^{11}$ Ni'matul Huda, (2008), UUD 1945 dan Gagasan..., Op.Cit., hlm 29-30.
} 
batu uji pengujiannya. UU No. 12 Tahun 2011 tentang Pembentukan Peraturan Perundang-Undangan sebagaimana yang telah diubah dengan UU No. 15 Tahun 2019. Dalam ketentuan Pasal 7 ayat (1) UU No. 15 Tahun 2019 telah mengatur terkait jenis dan hierarki norma hukum yang menjadi parameter jika nantinya terjadi judicial review atas suatu norma hukum, maka akan menunjukan kompetensi kekuasaan mana antara Mahkamah Konstitusi atau Mahkamah Agung yang berwenang melakukan judicial review atas norma tersebut. Adapun hierarki norma yang diatur dalam Pasal 7 ayat (1) meliputi: (1) Undang-Undang Dasar Negara Republik Indonesia Tahun 1945; (2) Ketetapan Majelis Permusyawaratan Rakyat Republik Indonesia; (3) UndangUndang/Peraturan Pemerintah Pengganti Undang-Undang; (4) Peraturan Pemerintah; (5) Peraturan Presiden; (6) Peraturan Daerah Provinsi; dan (7) Peraturan Daerah/Kota.

Meskipun secara konstitusional kewenangan judicial review antara Mahkamah Konstitusi dan Mahkamah Agung sudah diatur dan dibagi secara eksplisit oleh konstitusi. Namun, nyatanya dalam praktik di lapangan keputusan yang dikeluarkan antara kedua lembaga kekuasaan kehakiman ini justru sering menimbulkan polemik dalam sistem hukum Indonesia sebagai akibat dari adanya dualisme judicial review, memberikan kewenangan judicial review yang sama dengan tingkatan yang berbeda kepada dua lembaga kekuasaan kehakiman yang berbeda tapi sederajat tentu saja akan menimbulkan problematik.

Adanya dualisme judicial review yakni di Mahkamah Konstitusi dan Mahkamah Agung menimbulkan persoalan meski menggunakan jenjang norma yang berbeda dan tidak sederajat. Hal ini bukan hanya pada persoalan teknis semata yang diperbaiki. Akan tetapi persoalan potensialnya adalah bahwa sistem hukum kita mempraktikkan teori hukum berjenjang (stufenbau theory), artinya berlaku asas lex superior derogat lex inferior, dimana peraturan yang lebih rendah tidak boleh bertentangan dengan peraturan perundang-undangan yang lebih tinggi derajatnya. Dalam konteks ini setiap norma dituntut berada dalam satu frekuensi dengan norma yang tertinggi, tetapi menjadi aneh apabila dalam proses judicial review dilakukan oleh dua lembaga kekuasaan kehakiman yang berbeda atap, tentu saja akan terdapat banyak perbedaan, baik mekanisme maupun paradigma hukum para hakimnya. ${ }^{12}$

Kedua lembaga yakni Mahkamah Konstitusi dan Mahkamah Agung menggunakan tolak ukur hukum yang berbeda dalam menjalankan fungsi pengujiannya sehingga dapat saja berujung pada putusan yang berbeda secara mencolok. Hal inilah yang harus difikirkan, karena perbedaan putusan menimbulkan ketidakpastian hukum. Apakah kita ingin terus membiarkan terjadinya konflik hukum akibat adanya perbedaan pandangan antara kedua cabang kekuasaan kehakiman ini dalam menafsirkan suatu norma.

Judicial review yang dominan dipraktikkan di dunia, dikelompokan menjadi 2 (dua) sistem, yaitu centralised system (sistem yang terpusat) merupakan sistem pengujian yang hanya dilakukan dan difokuskan oleh satu lembaga saja, misalnya oleh Mahkamah Agung, Mahkamah Konstitusi, atau lembaga khusus lainnya. Sistem yang kedua adalah decentralised system (sistem tidak terpusat) berbeda dengan sistem yang pertama, jika pada sistem kedua pengujian tidak hanya dilakukan oleh satu badan

\footnotetext{
${ }^{12}$ Badan Pembinaan Hukum Nasional Kementerian Hukum dan HAM RI, Pengkajian Konstitusi Tentang Problematika Pengujian Peraturan Perundang Undangan, (Jakarta: Tim Pengkajian Konstitusi Tentang Problematika Pengujian Peraturan Perundang-Undangan), hlm 30-31.
} 
peradilan saja. ${ }^{13}$ Pengujian dengan decentralised system seperti dipraktikkan di negara Amerika, dimana Mahkamah Agung dan peradilan yang berada di bawahnya sama-sama berwenang memutuskan perkara judicila review. Namun yang perlu ditegaskan bahwa meskipun badan peradilan dibawah Mahkamah Agung juga berwenang melakukan judicial review tetapi semuanya berada dalam satu atap di bawah naungan Mahkamah Agung. Artinya judicial review yang diputuskan oleh badan peradilan di bawah Mahkamah Agung bisa dilakukan banding ke peradilan yang berada di atasnya, dengan demikian tidak akan menimbulkan konflik hukum antara satu putusan dengan putusan lain karena putusan akhirnya tetap berada dibawah kendali Mahkamah Agung, sehingga menjamin adanya kepastian hukum.

Kewenangan judicial review merupakan perwujudan dari prinsip checks and balances yang menempatkan semua lembaga negara pada posisi yang setara, sehingga dapat saling kontrol dan saling mengimbangi dalam praktik penyelenggaraan negara. ${ }^{14}$ Dalam konteks judicial review bekerjanya prinsip checks and balance ditandai dengan hadirnya putusan-putusan atas perkara judicial review yang dilaksanakan oleh seluru kalangan, artinya putusan-putusan tersebut tidak menimbulkan polemik.

Pilihan pemberian sepenuhnya kewenangan judciail review kepada Mahkamah Konstitusi merupakan pilihan politik hukum yang tepat, karena keberadaan Mahkamah Konstitusi memang didesain untuk menangani perkara ketatanegaraan atau perkara konstitusi guna menegakkan prinsip negara hukum demokratis. Oleh karena itu, Mahkamah Konstitusi selain sebagai penjaga konstitusi, Mahkamah Konstitusi juga merupakan penafsir tertinggi konstitusi (the sole interpreter of constitution).

\section{Persoalan Teknis Judicial Review di Mahkamah Agung}

Persoalan rumit lain yang akan terjadi apabila model pengujian peraturan perundangundangan tetap berada dalam dua atap adalah dalam hal penentuan subjek pengujian, bilamana pada saat dilakukan judicial review peraturan perundang-undangan dibawah Undang-Undang terhadap Undang-Undang (misalnya: Peraturan Pemerintah, Peraturan Presiden, dan Peraturan Daerah), namun produk hukum yang diuji tersebut tidak bertentangan secara langsung dengan Undang-Undang sebagai batu uji tetapi bertentangan langsung dengan aturan yang lebih tinggi, dalam hal ini Undang-Undang Dasar.

Tentu hal ini akan menimbulkan kerumitan tersendiri untuk menentukan siapa subjek yang berhak untuk melakukan judicial review,apakah Mahkamah Agung atau Mahkamah Konstitusi yang berwenang untuk melakukan pengujain tersebut. Jika melakukan penafsiran secara hukum, Mahkamah Agung tidak berwenang dalam pengujian tersebut, karena Mahkamah Agung hanya berwenang jika pengujiannya menggunakan batu uji Undang-Undang sedangkan peraturan yang hendak diuji tidak bertentangan dengan Undang-Undang terkait tetapi bertentangan langsung dengan Undang-Undang Dasar, yang mana pengujiannya bukan ranah dari Mahkamah Agung. Sebaliknya juga tentu bukan merupakan kompetensi Mahkamah Konstitusi karena produk yang diuji kedudukannya di bawah Undang-Undang. Persoalan seperti ini

\footnotetext{
${ }^{13}$ Jimly Assihiddiqie,(2006), Perihal Undang-Undang, Kepanitraan MKRI, hlm 7.

14 Ni'matul Huda, (2018), Kekuatan Eksekutorial Putusan Mahkamah Konstitusi, Cetakan Pertama, Yogyakarta: FH UII Press, hlm 2.
} 
menimbulkan kerumitan dalam penyelesaian sengketa judicial review. ${ }^{15}$ Tentu saja kerumitan ini tidak akan terjadi jika kewenangan judicial review diintegrasikan dalam satu atap. Secara teknis pelaksanaan kewenangan judicial review di Mahkamah Agung menimbulkan banyak sekali kelemahan sehingga menimbulkan berbagai kritik oleh akademisi hukum, praktisi hukum, dan para pihak pencari keadilan. Persoalan yang selalu disoroti, diantaranya:

Pertama, mekanisme pemeriksaan yang tidak transparan serta hukum acara yang tidak jelas menyebabkan judicial review di Mahkamah Agung sering mendapat kritik dari para pencari keadilan sekalipun persidangan di Mahkamah Agung dinyatakan dibuka dan terbuka untuk umum, namun sejatinya dalam pemeriksaan perkara hak uji materil pihak-pihak terkait tidak dihadirkan dalam persidangan. Demikian pula dengan pemeriksaan para saksi, untuk keterangan para ahli diajukan dalam bentuk tertulis, bila dibutuhkan.Persidangan di Mahkamah Agung pengujiannya hanya dilakukan terhadap berkas permohonan yang diajukan oleh pemohon dan berkas jawaban yang dari pihak termohon. Sementara persidangan di Mahkamah Konstitusi menerapkan prinsip audi et alteram partem, dimana para pihak akan didengarkan keterangannya oleh majelis hakim guna mencari fakta hukum dalam persidangan.

Padahal permohonan judicial review yang dilakukan oleh Mahkamah Agung tidak hanya menguji aspek hukumnya saja, tapi juga menguji fakta hukum. Selain itu putusan yang dikeluarkan juga bersifat final and binding dan oleh karena objek pengujiannya norma hukum umum-abstrak, maka putusannya pun berdampak sangat luas bagi publik. ${ }^{16}$ Dengan mekanisme seperti itu maka pengujian di Mahkamah Agung terkesan sangat prosedural dan jauh dari kata progresif dibandingkan dengan Mahkamah Konstitusi.

Beban perkara yang dihadapi Mahkamah Agung menjadi salah satu alasan proses beracara Mahkamah Agung menjadi tidak efektif. Hal ini pun dibenarkan oleh Kepala Biro Hukum dan Humas Mahkamah Agung, Abdullah menyatakan bahwa perkara yang ditangani Mahkamah Agung cukup banyak, seperti perkara kasasi, perkara peninjauan kembali (PK), dan perkara hukumnya lainnya. Banyaknya perkara tersebut membuat Mahkamah Agung bekerja mengejar waktu (target). ${ }^{17}$ Sebagai perbandingan, misalnya pada tahun 2018 jumlah perkara yang ditangani Hakim Agung Kamar Tata Usaha Negara sebanyak 4.378 perkara, sementara jumlah perkara yang ditangani oleh Mahkamah Konstitusi pada tahun 2018 sebanyak 151 perkara. ${ }^{18}$ Dari sampel data tahun 2018 tersebut menunjukan bahwa terdapat perbandingan yang sangat jauh.Banyaknya beban perkara yang ditangani oleh Mahkamah Agung merupakan hal yang wajar, mengingat Mahkamah Agung merupakan puncak dari semua peradilan umum yang

${ }^{15}$ Janpatar Simamora, (2013), Analisis Yuridis Terhadap Model Kewenangan Judicial Review Di Indonesia, Fakultas Hukum Universitas HKBP Nommensen, Vol.25, No.3, Oktober, hlm 390.

${ }^{16}$ Maftuh Effendi,(2013), Kewenangan Uji Materill Peraturan Perundang-Undangan di Bawah Undang-Undang, Jakarta: Pusat Penelitian dan Pengembangan Mahkamh Agung RI, hlm 46

${ }^{17}$ https://Www.Google.Com/Amp/S/Amp.Kompas.Com/Nasional/Read/2018/04/10/10161061/Sid ang-Uji-Materil-Tertutup-Ma-Sebut-Karena-Batas-Waktu. Diakses 29 Februari 2020.

${ }^{18}$ Data dari Lembaga Kajian \& Advokasi Independensi Peradilan.Lihat https://leip.or.id/statistikdata-perkara-mahkamah-agung.diakses 29 Februaru 2020. 
berada dibawahnya. Olehnya itu Mahkamah Agung tidak perlu lagi dibebankan dalam kewenanganjudicial review. ${ }^{19}$

Kedua, secara teknis perbedaan yang mencolok antara Mahkamah Konstitusi dan Mahakamh Agung adalah tidak adanya mekanisme persidangan jarak jauh (teleconference) di Mahakamh Agung, sementara di Mahkamah Konstitusi tersedia mekanisme persidangan jarak jauh. Dengan mekanisme teleconference akan mempermudah para pihak terutama yang berada di daerah yang jangkauannya jauh dengan institusi Mahkamah Agung, yang ingin melakukan judicial review sebuah perda.

Dengan tidak adanya mekanisme persidangan jarak jauh akan sangat mempersulit para pencari keadilan, mengingat secara geografis Indonesia merupakan negara kepulauan besar yang terdiri dari banyak pulau sehingga menjadi beban bagi masyarakat atau pemerintah daerah. Serta dengan proses pengujian yang tidak transparan dalam persidangan uji materil maka bisa dikatakan bahwa proses pengujian yang selama ini dilakukan di Mahkamah Agung telah melanggar asas independensi dan impartial juga asas peradilan cepat dan biaya ringan. ${ }^{20}$

Melihat banyaknya perkara yang ditangani oleh Mahkamah Agung setiap tahunnya yang berakibat pada tidak efektifnya proses beracara, khususnya untuk perkara uji materi, maka sudah saat untuk melakukan pembenahan dengan mengurangi beban perkara yang dihadapi oleh Mahkamah Agung. Salah satu langkah yang bisa dilakukan adalah dengan merubah sistem judicial review dimana Mahkamah Agung tidak perlu diberikan kewenangan melakukanjudicial review lagi, kewenangan tersebut cukup dimiliki oleh Mahkamah Konstitusi. Pilihan tersebut menjadi semakin rasional mengingat kemungkinan akan terjadi pengurangan beban perkara yang ditangani oleh Mahkamah Konstitusi ketika sudah dibentuknya peradilan khusus yang menangani sengketa pilkada.

Keberadaan peradilan khusus pilkada telah ditegaskan dalam ketentuan Pasal 157 ayat (1) bahwa: "perkara perselisihan hasil pemilihan diperiksa dan diadili oleh badan peradilan khusus". Pembentukan peradilan khusus pilkada direncanakan akan dibentuk sebelum diselenggarakan pilkada serentak $2024 .^{21} \mathrm{Jika}$ peradilan khusus pilkada akan terbentuk tentu jumlah perkara yang ditangani Mahkamah Konstitusi akan berkurang secara drastis, mengingat banyak perkara yang masuk di Mahkamah Konstitusi adalah sengketa pilkada.

\section{Judicial Review Satu Atap Dibawah Mahkamah Konstitusi}

Dalam konsep negara hukum demokratis (democracy rechsttaat) pembuatan kebijakan untuk pelaksanaan pemerintahan tidak hanya di fokuskan pada aspek legalistas

\footnotetext{
${ }^{19}$ Uji materil di Mahkamah Agung dilakukan oleh hakim yang berada di Kamar Tata Usaha Negara, oleh karena itu penulis hanya membandingkan jumlah perkara yang ditangani oleh hakim di Kamar Tata Usaha Negara.Jika mengambil jumlah perkara secara keseluruan di Mahkamah Agung maka tentu tidak tepat jika diperbandingkan karena banyak jenis sengketa yang ditangani oleh Mahkamah Agung dengan sistem kamar berbeda, sesuai dengan jenis perkara yang dihadapi.

${ }^{20}$ Adapun proses persidangan di Mahkamah Agung selama ini telah melanggar Pasal 13 UndangUndang Nomor 48 Tahun 2009 tentang Kekuasaan Kehakiman. Ditegaskan bahwa seluruh pemeriksaan pengadilan terbuka untuk umum dan putusan pengadilan hanya sah dan memiliki kekuatan hukum apabila diucapkan dalam sidang terbuka untuk umum.

21 Lihat ketentuan Pasal 157 Undang-Undang Nomor 10 Tahun 2016 tentang Pemilihan Gubernur, Bupati, dan Walikota
} 
kebijakan tersebut (rechmatigheid van bestuur), tetapi harus fokus juga pada aspek efisiensi (doelmatigheid) dan aspek efektivitasnya (doeltreffenheid) dari kebijakan yang dibuat agar pelaksanaannya bisa menimbulkan kemanfaatan dan keadilan bagi masyarakat luas. ${ }^{22}$ Apabila tolak ukur tersebut kita kontekskan dengan sistem judicial review yang dipraktikkan saat ini berada dalam dua atap sering menimbulkan koflik yang berujung pada tidak tercapainya kepastian hukum, efisiensi dan efektivitas bagi para pencari keadilan. Dengan demikian perlu adanya politik hukum pembaharuan sistem judicial review dengan mekanisme satu atap yang kewenangan judicial review bisa difokuskan kepada Mahkamah Konstiusi selaku pelindung konstitusi (the guardian of constitution).

Pilihan judicial review dengan sistem satu atap yang diintegrasikan di bawah Mahkamah Konstitusi didasari pada pertimbangan bahwa kewenangan judicial review berada dalam dua atap tidak hanya menyebabkan terjadinya pertentangan putusan antara Mahkamah Konstitusi dan Mahkamah Agung tetapi juga melahirkan polemik hukum yang cukup serius dalam praktik ketatanegaraan saat ini oleh karena putusan kedua Lembaga tersebut sama-sama memiliki kekuatan hukum mengikat dan tidak saling membatalkan satu sama lain dan apabila tidak diatasi tentu akan menjadi preseden buruk dalam praktik ketatata negaraan kita.

Selain itu, pembentukan peradilan khusus penyelesaian sengketa pemilihan kepala daerah yang berakibat pada mengurangnya beban kerja Mahkamah Konstitusi sehingga Mahkamah Konstitusi hanya fokus pada tugas utamanya sebagaimana dirumuskan dalam pasal 24C UUD NRI Tahun 1945 yakni menguji undang-undang terhadap Undang Undang Dasar, memutus sengketa wewenang lembaga negara yang kewenangannya diberikan oleh Undang Undang Dasar, memutus pembubaran partai politik, dan memutus perselisihan tentang hasil pemilihan umum. Dari wewenang tersebut, hakim-hakim Mahkamah Konstitusi nyaris hanya mengadili sengketa pengujian undang-undang terhadap Undang-Undang Dasar, itupun tidak rutin jika di bandingkan dengan beban kerja hakim-hakim di Mahkamah Agung sebagai judex juris sehingga tepat kiranya jika pengujian semua norma hukum terpusat di Mahkamah Konstitusi.

\section{KESIMPULAN}

Bedasarkan permasalahan sebagaimana terurai dalam pembahasan diatas maka yang menjadi kesimpulan adalah: Proses judicial review yang dipisahkan antara Mahkamah Konstitusi dan Mahkamah Agung merupakan pilihan sistem yang tidak ideal baik secara teknis maupun teoritis, serta berpotensi menimbulkan konflik hukum yang rumit. Oleh karena itu, kedepannya perlu dibuat desain sistem yang tepat dengan cara mengintegrasikan kewenangan pengujian paraturan perundang-undangan kepada satu lembaga saja, yaitu Mahkamah Konstitusi. Kedepannya Mahkamah Konstitusi harus berfungsi sebagai penafsir tunggal peraturan perundang-undangan karena Mahkamah Konstitusi merupakan penafsir konstitusi. Mahlamah Konstitusi harus mampu menjamin konsistensi peraturan perundang-undangan, olehnya itu kewenangan Mahkamah Konstitudi difokuskan pada penyelesaian konflik-konflik hukum ketatanegaraan, sementara Mahkamah Agung idealnya difokuskan pada penyelesaian konflik hukum

${ }^{22}$ Philipus M. Hadjon, et.ac., (2012), Hukum Administrasi dan Tindak Pidana Korupsi, Cetakan Kedua, Yogyakarta: Gaja Mada University Press, hlm 6-7 
pidana-perdata. Menempatkan Mahkamah Konstitusi sebagai lembagan tunggal pengujian norma (judicial review) adalah politik hukum yang diperlukan saat ini dalam rangka mewujudkan peradilan yang efektif terlebih dalam sistem bifurkasi sebagaimana dianut Indonesia saat ini serta mencegah polemik tumpang tindih putusan yang tidak memberikan kepastian hukum kepada pencari keadilan khususnya menegani pengujian norma sebagaimana yang terjadi saat ini. Kebijakan tersebut (judiacial review satu atap) tepat dilakukan oleh karena kewenagan penyelesaikan perselisihan hasil pemilihan kepala daerah tidak lagi menjadi wewenang Makamah Konstitusi manakalah telah terbentuk peradilan khusus penyelesaian sengketa pemilihan kepada daerah. Dengan adanya pengujian norma (judicial review) satu atap di Mahkamah Konstitusi maka Mahkamah Agung akan lebih fokus pada tugasnya sebagai Judex Juris yang pada girannya akan mewujudkan peradilan yang efektif.

\section{Daftar Pustaka}

Abdul Hakim Garuda Nusantara, "Mahkamah Konstitusi: Perspektif Politik dan Hukum”, Kompas, 24 September 2002.

Abdul Mukthie Fadjar, Hukum Konstitusi Dan Mahkamah Konstitusi, Cetakan Pertama, Jakarta: Konstitusi Press dan Citra Media, 2006.

Jimly Ashiddiqie, Model-Model Pengujian Konstitusional Di Berbagai Negara, Jakarata: Konstitusi Press, 2005.

, Perihal Undang-Undang, Jakarta: Kepanitraan MKRI, 2006.

Janpatar Simamora, Analisis Yuridis Terhadap Model Kewenangan Judicial Review Di Indonesia, Fakultas Hukum Universitas HKBP Nommensen, Vol.25, No.3, Oktober 2013.

Maftuh Effendi, Kewenangan Uji Materill Peraturan Perundang-Undangan di Bawah Undang-Undang, Jakarta: Pusat Penelitian dan Pengembangan Mahkamh Agung RI, 2013.

Ni'matul Huda, UUD 1945 dan Gagasan Amandemen Ulang, Jakarta: Rajawali Pers, 2008).

, Kekuatan Eksekutorial Putusan Mahkamah Konstitusi, Cetakan Pertama, Yogyakarta: FH UII Press, 2018.

Philipus M. Hadjon, et.ac.,Hukum Administrasi dan Tindak Pidana Korupsi, Cetakan K2, Yogyakarta: Gaja Mada University Press, 2012.

Tim Pengkajian Konstitusi Tentang Problematika Pengujian Peraturan PerundangUndangan, Pengkajian Konstitusi Tentang Problematika Pengujian Peraturan Perundang Undangan, (Jakarta: Badan Pembinaan Hukum Nasional Kementerian Hukum dan HAM RI, 2014.

Lembaga Kajian \& Advokasi Independensi Peradilan.Lihat https://leip.or.id/statistikdata-perkara-mahkamah-agung.diakses 29 Februaru 2020.

https://Www.Google.Com/Amp/S/Amp.Kompas.Com/Nasional/Read/2018/04/10/1016 1061/Sidang-Uji-Materil-Tertutup-Ma-Sebut-Karena-Batas-Waktu. Diakses 29 Februaru 2020. 


\section{Peraturan Perundang-Undangan}

Undang-Undang Dasar Negara Republik Indonesia Tahun 1945

Undang-Undang Nomor 48 Tahun 2009 tentang Kekuasaan Kehakiman

Undang-Undang Nomor 10 Tahun 2016 tentang Pemilihan Gubernur, Bupati, dan Walikota.

Putusan Mahkamah Agung Nomor 103K/Pid/2007.

Putusan Mahkamah Konstitusi No. 4/PUU-V/2007. 